\title{
Urban planning in riverfront areas. A case study of a mediterranean city: Terrassa (Catalonia, NE Spain)
}

\begin{abstract}
Since 1980, Spain has introduced urban regeneration plans in various cities with the aim of integrating the river environment into the urban system. This process has proved most challenging in cities whose rivers present extreme features, as is the case with Terrassa (Catalonia, NE Spain), a medium-sized city (215,000 inhabitants in 2013) whose three river courses are prone to flash flooding. Through the critical analysis of urban planning undertaken in the city from the fifties to the present day, we show that the urban evolution of each of the three intermittent streams has differed significantly. Thus, while the plans affecting el Torrent de Vallparadis have led to the construction of Terrassa's central park, the plans for la Riera del Palau and la Riera de les Arenes have impeded, in their own ways, full urban integration.

Keywords

Urban planning $\cdot$ urban regeneration $\cdot$ riverfront $\cdot$ Spanish medium-sized cities • Terrassa

(C) University of Warsaw - Faculty of Geography and Regional Studies
\end{abstract}

Albert Santasusagna Riu', Joan Tort Donada ${ }^{2}$

'Department of Physical Geography and Regional Studies, Faculty of Geography, University of Barcelona, Spain e-mail: asantasusagna@ub.edu

2Department of Physical Geography and Regional Studies, Faculty of Geography, University of Barcelona, Spain e-mail: jtort@ub.edu

Received: 1 February 2015 Accepted: 19 August 2015
Introduction

The history of mankind is closely tied to the earth's rivers, the primary determinant of the location of urban settlements. Rivers have not only influenced the shape and distribution of our towns and cities, they have also determined their economic and social relations. Indeed, man has shown a great interest in waterways from the time the advantages they offered (in particular those of an economic nature) first became apparent. Apart from supplying essential water resources, rivers have permitted the rapid and cheap transportation of goods between both river and sea ports. The trading relations established between different regions, peoples and cultures separated by water masses of different types have been well documented. One need only look at the raison d'être of the great European capitals and cities, some sited on or near a river, others gradually expanding on both riverbanks, for example: Paris and the Seine, London and the Thames, Rome and the Tiber, Vienna and the Danube and Warsaw and the Vistula. In short, river ports and waterfronts the origins of a city - have ensured economic advancement, intellectual progress and the cultural development of human society as a whole.

However, the relationship between cities and their rivers has been a highly complex one, constituting an inescapable challenge of coexistence between two very different systems (Ureña 1999): the river environment, characterized by change, diversity and the occasional occupation of space during flood events; and the urban environment, uniform, continuous, of exclusive uses and man-made products. Each city-river case is unique, and riverfronts have been treated quite distinctly by urban planners depending on the characteristics of the river environment, for example, the hydromorphological factors of its basin, and flood episodes linked to its hydrological regime; and also the characteristics of the urban environment: publicprivate investments or the absence of thereof; processes of marginalization or, to the contrary, the creation of new urban hubs, albeit always governed by a logic of "vicious" and "virtuous circles" (Penning-Rowsell 1997). In the European case, during the 1980 s and 1990s plans were implemented for the environmental restoration and urban regeneration of riverfronts, and they have allowed the natural environment to be integrated into the urban fabric. Cities such as London (Donofrio 2007), Paris (Djament-Tran 2012), Hamburg (Hans 2008), Manchester (APEM \& Environment Agency 2010), Lisbon and Genoa (Moretti 2010), Lyon (Bravard 2004), Rotterdam (Moretti 2008) and Thessaloniki (Tastoglou \& Vagiona 2012) are paradigmatic examples of the strategic renewal of riverfronts and waterfronts. These new policies for managing urban river areas responded, firstly, to the emergence - in the broadest sense - of the environmental movement and secondly, to the will to reconcile the restoration of the river ecosystem with its use by the city dwellers. Riverfront areas have gone from being perceived as "marginal" and "marginalized" spaces (Panareda 2009) to forming part of a new model that, to varying degrees, reassesses their social, economic and landscape value, enabling citizens to enjoy a city that has managed to turn around and face its river once more (Ribas 2012). Undoubtedly, these new management policies have been favoured by the adoption, in 2000, of the Water Framework Directive, which has contributed to establishment of a series of targets concerning environmental quality, which the urban planners of the $21^{\text {st }}$ century have 

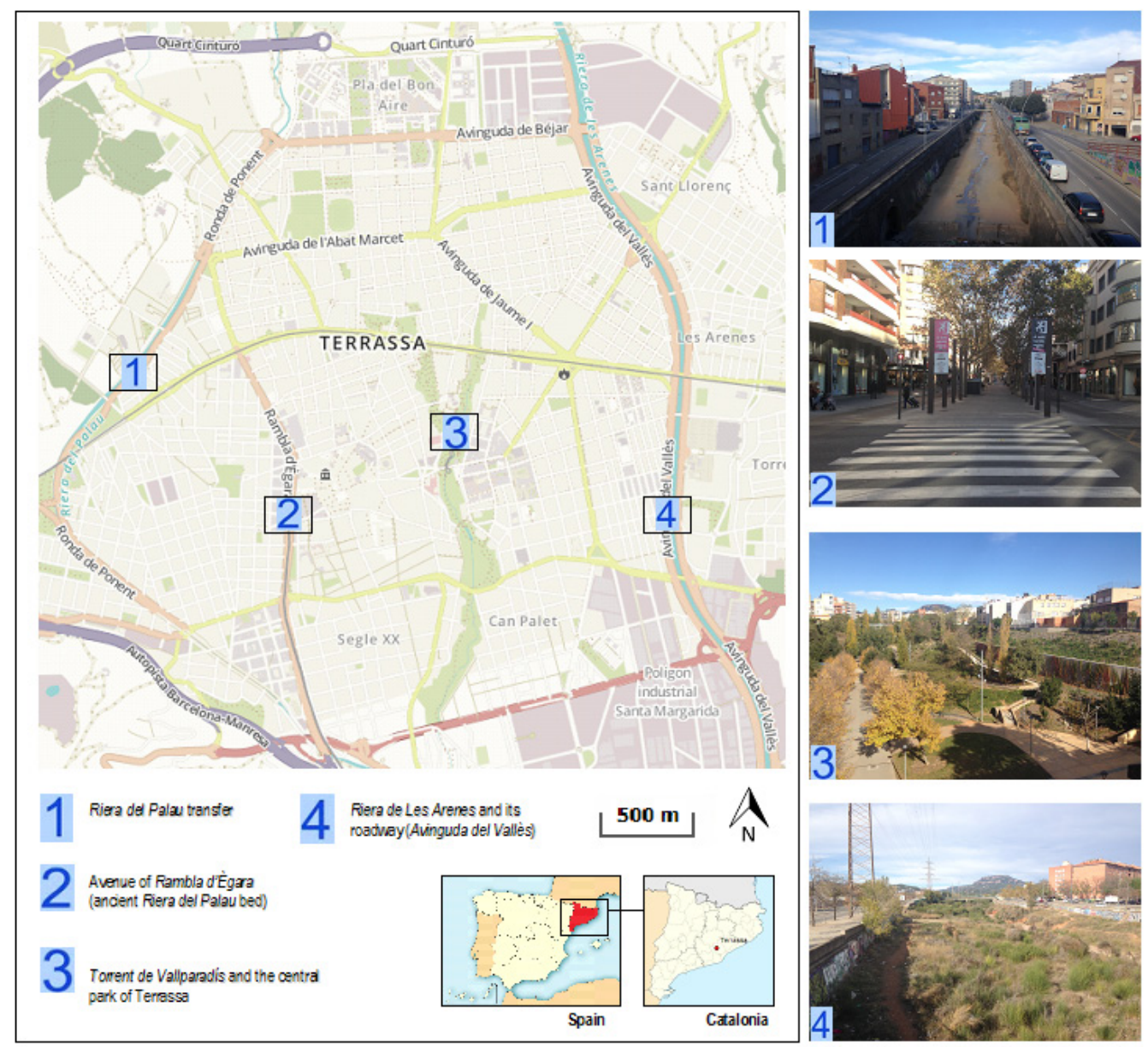

Figure 1. Map showing the main rieras, or intermittent rivers, in the city of Terrassa, together with the course taken by the riverbed la Riera del Palau. The additional two figures show the location of Terrassa in Catalonia and in Spain

Source: Based on a modification of the original topographic map (1:10,000) @OpenStreetMap and the original administrative maps of CWikipedia, licensed under open database licence (ODbL). The photographs are the authors' own, taken in December 2013

assumed as their main goals within a discourse that emphasizes, above all, the preservation and restoration of watercourses.

Against this backdrop, the main objective of this study is to address the evolution of urban planning projects that have dealt with the three main torrential or intermittent river courses (rieras) in the city of Terrassa (Catalonia, NE Spain), within the framework of the integrated understanding of the fluvial and urban environments constituting a unique and complex reality.

\section{Materials and Methods}

Terrassa, a medium-sized Spanish city - with 215,517 inhabitants as of 2014, according to official sources (IDESCAT), and with considerable weight in the Barcelona metropolitan zone - does not present the classic settlement pattern of a river city, that is, straddling a great river. Rather it is full of small, intermittent streams or rieras, most of which have a dry riverbed throughout most of the year. The three main torrential river courses in Terrassa are la Riera del Palau, which currently serves as an inter-basin transfer, since its course was diverted as a result of the great flood of 1962; el Torrent de Vallparadís, which forms the central feature of the city's central park and is home to important pre-Romanesque remains; and la Riera de les Arenes, a fully channelled course with protection banks, in an obviously marginal situation (Figure 1).

The hydrological regime of Terrassa's three rieras typifies that of small and medium-sized river basins in the Mediterranean area of the Iberian Peninsula. Thus, during most of the year, the regime is characterized by a discharge that is minimal or negligible. However, during episodes of 'flash' flooding (MoralItuarte, 1997) the discharge can reach rates of $700 \mathrm{~m}^{3} / \mathrm{s}$, as was the maximum discharge recorded during the flooding of la Riera de les Arenes in September 1962. Of Terrassa's three main river courses, la Riera de les Arenes is the largest with a total length of $15 \mathrm{~km}$ and a basin area of $30 \mathrm{~km}^{2}$. In contrast, el Torrent de Vallparadís and la Riera del Palau are roughly half as long (c. $7 \mathrm{~km}$ ) and run almost entirely through the urban area of Terrassa (that is, through the "constructed" city).

Terrassa's town planning has developed, in the main, thanks to the approval and implementation of the first law on urban planning in Spain (Ley de 12 de mayo de 1956 sobre Régimen del Suelo y Ordenación Urbana). This law, which was not superseded until 2008, has served as the cornerstone of the country's planning and construction law. The planning instruments studied in this article are a direct result of this legislation and its subsequent 
MISCELLANEA GEOGRAPHICA - REGIONAL STUDIES ON DEVELOPMENT

Vol. $19 \cdot$ No. $3 \cdot 2015 \cdot$ pp. 14-21 •ISSN: 2084-6118 • DOI: 10.1515/mgrsd-2015-0015

Table 1. A list of the urban plans studied in this article from the 1950s to the present for Terrassa. In green, are those that were finally approved; and in red, those that were drafted but never definitively approved

\begin{tabular}{|c|c|c|c|}
\hline Terrassa's urban planning & Year of publication & Main authors of the project & Final approval \\
\hline Plan General de Ordenación Urbana & 1951 & Manuel Baldrich (architect) & \\
\hline Plan General de Ordenación Urbana & 1958 & $\begin{array}{l}\text { Jordi Alsius, Josep Pratmarsó } \\
\text { (architects) }\end{array}$ & \\
\hline Planes de urgencia & $1962-63$ & Terrassa City Hall & \\
\hline Plan General de Ordenación Urbana & 1965 & Joan Baca (architect) & \\
\hline Plan General de Ordenación Urbana & 1983 & $\begin{array}{l}\text { Gerencia Municipal de Urbanismo } \\
\text { (interdisciplinary team) }\end{array}$ & \\
\hline $\begin{array}{c}\text { Plan especial de ordenación del Parque de } \\
\text { Vallparadís }\end{array}$ & 1987 & $\begin{array}{c}\text { Manuel Ribas i Piera (architect and } \\
\text { planner) }\end{array}$ & \\
\hline Plan de Ordenación Urbanística Municipal & 2003 & $\begin{array}{l}\text { Gerencia Municipal de Urbanismo } \\
\text { (interdisciplinary team) }\end{array}$ & \\
\hline
\end{tabular}

Source: Authors' own composition.

amendments. ${ }^{1}$ The plan general de ordenación urbana (that is the general urban land-use plan, henceforth the PGOU) is the basic instrument for the integrated territorial planning of one or more municipalities: in which land is classified and regulated and the fundamental elements of the system of amenities are defined. While the plan especial (that is, the special plan, henceforth the $\mathrm{PE}$ ) provides for the specific applications of the PGOU. The plan de ordenación urbanística municipal (that is, the municipal urban management plan, henceforth the POUM) has come to characterise the modernization of urban planning regulations in Catalonia, ${ }^{2}$ and is the equivalent of the PGOU. And, finally, the plan de urgencia or the contingency plan is implemented in extraordinary situations in response to, for example, a flood episode.

In this context, we will analyse and summarize the evolution of local town planning, which historically has been responsible for the management (or lack thereof) of the river environment in Terrassa. Our analysis of this urban planning involves a study of the plans generated since the 1950s, which is when the first PGOU was drawn up, down to the present day. This body of norms and regulations includes eight documents and their annexes. These can be classified as PGOUs (1951, 1958, 1965, 1983), two contingency plans $(1962,1963)$, one PE (1987) and one POUM (2003), all were inspected at the Municipal Archives of Terrassa (Table 1). Our analysis of these planning regulations involved identifying, selecting and comparing the city's main urban projects since 1950, with a particular concern for those areas or sectors of the city within the three river basins examined in this study.

\section{Results and Discussion}

The 1951 PGOU or the Baldrich Plan. El Torrente de Vallparadís, park and urban axis

To comply with prevailing urban planning regulations, in October 1951 a new general urban land-use plan (PGOU) was presented to the city of Terrassa by the architect Manuel

'Specifically, Ley 19/1975, de 2 de mayo, de reforma de la Ley sobre Régimen del Suelo y Ordenación Urbana and Real Decreto 2159/1978, de 23 de junio, por el que se aprueba el Reglamento de Planeamiento para el desarrollo y aplicación de la Ley sobre Régimen del Suelo y Ordenación Urbana.

${ }^{2}$ Following a Supreme Court ruling in 1997, each Autonomous Community in Spain was granted optional powers with regard to its urban planning legislation. Consequently, a range of different planning laws and instruments have been developed.
Baldrich. One of the great challenges of the plan was to set aside a minimum of $10 \%$ of the total urban area of the municipality for open spaces, i.e. green zones and areas for sports and leisure activities. At that time Terrassa had a total of just 2.74 hectares of open space, corresponding to $0.75 \%$ of its total urban area. In order to meet the planning regulation's minimum requirements, the plan foresaw a growth in the city's open space to a total of 120 ha -90 ha for green zones and 30 ha for areas dedicated to sports activities - over the next fifty years, increasing from $0.45 \mathrm{~m}^{2}$ to 7.5 $\mathrm{m}^{2}$ of open spaces per inhabitant. The document considered this increase in new public green spaces as absolutely necessary for Terrassa, given the poor quality of life in the industrial city:

"Today Terrassa, in reality boasts no more than the central boulevard formed by the Rambla, and has no public park whatsoever. This is doubly unfortunate, because a heavily industrialised city needs to be able to draw a curtain across to separate the industrial from the residential areas and it requires, more than anything, free public space where city $d$ wellers can find rest and recreation when they come out of work". (Terrassa City Hall 1951a).

The main planning proposal contained in the PGOU that fulfilled the minimum requirements of open space was to be the development of the so-called "park-way" by the year 2000. A transversal communication project for the city of Terrassa, taking advantage of the river banks of el Torrent de Vallparadís as new green zones for the use and enjoyment of the people of Terrassa (Figure 2). The primary objective of the plan was that this new connection should become one of the city's main north-south arteries, and that it would facilitate direct communication with the surrounding towns, including Rubí, Matadepera and Sant Cugat. However, it was not envisaged as a multi-lane motorway nor were any plans undertaken to create new areas for vehicle parking. Essentially, what was proposed was that the original course of the torrent be respected; adapting the route taken by the road to the twists and turns of the riverbed, while also promoting the park's valuable historic and architectural heritage (primarily the pre-Romanesque churches of Sant Pere d'Ègara), and respecting as far as possible the stands of trees on the river banks and, ultimately, giving priority to public ways of access to the entire area (Ribas-Piera 1992). 


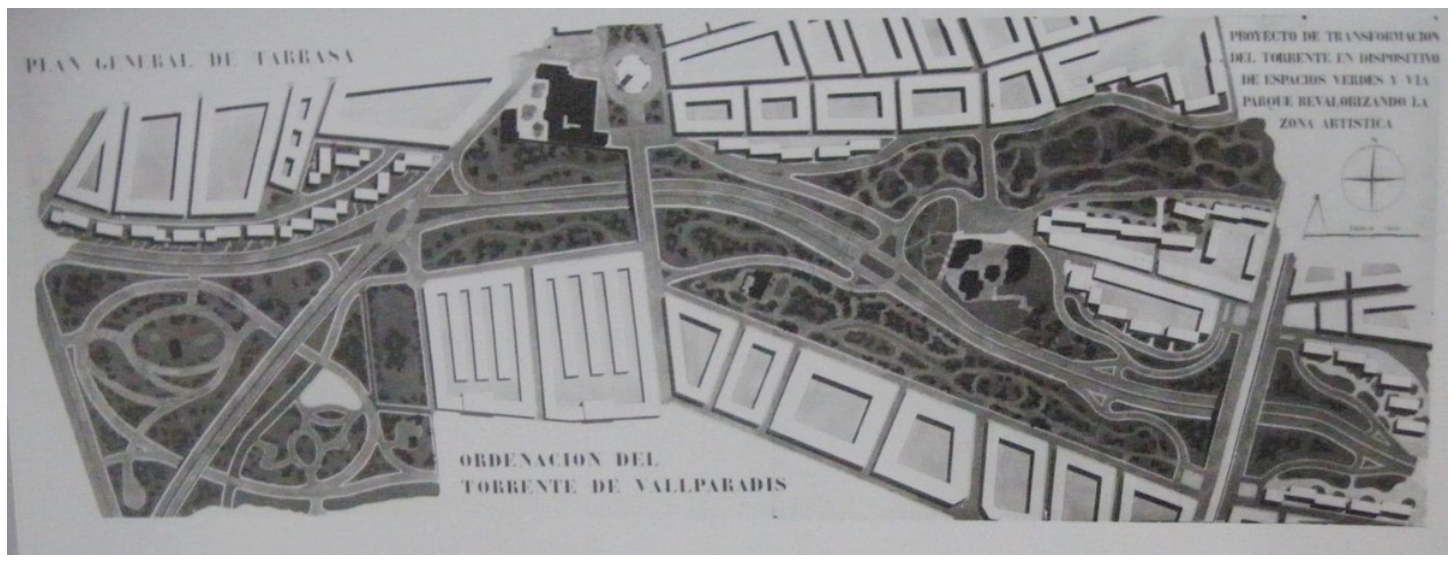

Figure 2. The park-way project designed by the architect, Manuel Baldrich Source: Pla General d'Ordenació Urbana de Terrassa (1951).

Although this plan focused virtually all its attention on the urban development project of the park-way, a further analysis allows us to make a number of findings about another of the city's main watercourses, la Riera de les Arenes. During the gestation of the plan, this riera was an example of a depressed marginal zone, ecologically as well as socially; the "vicious circle" of the environmental and urban degradation of its banks was clearly apparent. Although the volumes of water in this riera were scarce and badly contaminated, they were regular enough to permit the establishment of a small horticultural zone on its banks. A possibility exploited mainly by the migrants that had flooded into Terrassa from the rest of Spain during the fifties. ${ }^{3}$ The plan notes that the banks of la Riera de les Arenes had been converted into a continuous row of prefabricated buildings that had consolidated into a suburban area, typifying the slum phenomenon known in Spain as barraquismo. ${ }^{4}$ The plan considered la Riera de les Arenes as a "natural limit" for the city's expansion, hence the need to restore it. To this end, the architect Baldrich proposed reserving a green zone along its banks and introducing urban services in anticipation of population growth in this area, as well as constructing a new drainage system for the disposal of sewage and storm water.

\section{The 1958 PGOU. The "counterproposal"}

The enormous difficulties in obtaining a definitive approval for the 1951 PGOU, given the open struggle with the local oligarchy (Boix 1983a), led the Terrassa City Council to instruct architects Jordi Alsius and Josep Pratmarsó to draft a "counterproposal" - a new PGOU - so as to introduce the necessary amendments to facilitate its implementation. ${ }^{5}$ Terrassa would have to wait seven years, until 1958, for this plan to see light of day.

${ }^{3}$ Between the 1930 s and 1960 s, Catalonia experienced significant migratory flows from the economically depressed rural regions of Spain, including Andalusia and Extremadura. These internal migrations represented a rural exodus to industrial areas with a good supply of jobs, above all in the textile sector, with a large market to satisfy.

${ }^{4}$ The 1951 PGOU broadly defines the suburbs in these areas along the riera: "They are totally anarchic neighborhoods or suburban areas, and while they cannot be classified as suburbs of shack-like dwellings, they lack the most essential urban services: water electricity, paving and sewage disposal" (Terrassa City Hall 1951b). The plan is quite explicit in stating that they must be "eradicated" because of the risk that they will expand and create major problems for the city.

In the report accompanying the "counterproposal" it is made clear that "the plan should be implemented as they went along; as far as possible, seeking to strike the right balance between attempts to organize the urban environment and private interests" (Terrassa City Hall 1958b). The council sought above all a document of consensus so that they might reconcile positions with the large private property owners of Terrassa and so, eventually, approve a development plan to their liking.
The report accompanying the "counterproposal" was highly critical of the 1951 PGOU: concluding that the fifty-year time horizon was quite unrealistic and speaking out against the expropriations planned for the urban reforms. Yet, it gave the green light to the park-way project along el Torrent de Vallparadís without making any substantial changes: "it is a genuine natural park, and a logical move for the City Hall must be to reassess its value" (Terrassa City Hall 1958a). The fact that the original plan did not contemplate making any major expropriations, together with the 1956 entry into force of the new urban planning regulations and their renewed protectionist principles, ${ }^{6}$ meant the park-way project was virtually the only thing that the 1958 "counterproposal" did not jettison in its technical-economic analysis.

Despite being highly respectful of private property, it did not go far enough in protecting private interests and was never approved by City Hall, thus adding to the long list of urban planning failures.

The 1962 and 1963 contingency plans. The economic destruction by the 1962 flood

The terrible flood of 1962, which affected the whole of the Catalan comarca of Vallès Occidental and causing great damage to Terrassa, acted as a catalyst for the urban development of the city. City Hall devoted a budget of 328 million pesetas (about 2 million euros) for work aimed mainly at repairing and constructing water channels (storm water and wastewater collectors), rebuilding and improving paving, urbanizing the most badly hit areas and repairing municipal property damage (Table 2 and Figure 3).

The most important interventions were those that affected the city's main river courses. To protect its citizens, and to ensure a disaster of this kind never happened again, City Hall took drastic measures to calm the obvious concerns of the population and in the same year as the flood (1962), la Riera de les Arenes, and a number of other small local gullies, were deepened and channelled.

${ }^{6}$ The Ley de 12 de mayo de 1956 sobre régimen del suelo y ordenación urbana, a pioneering law in Spain in the area of urban planning, allowed various land use decisions proposed in the 1951 PGOU to be reconsidered. Thus, in the 1958 "counterproposal" the 'green zones' were now referred to as 'green protection zones', and the pre-Romanesque site and Ėgara castle were classified as 'protected historical monuments'. Despite this, not enough was done to make this protected status considered as "future green zones", no clear definition was provided as to what this proposal actually might mean. 
MISCELLANEA GEOGRAPHICA - REGIONAL STUDIES ON DEVELOPMENT

Vol. $19 \cdot$ No. $3 \cdot 2015 \cdot$ pp. 14-21 •ISSN: 2084-6118 • DOI: 10.1515/mgrsd-2015-0015

Table 2. Summary of the main items in the contingency budget (in pesetas and euros) dedicated to the urban renewal of Terrassa

\begin{tabular}{|c|c|c|}
\hline $\begin{array}{l}\text { Contingency } \\
\text { plans }\end{array}$ & Urban planning actions & $\begin{array}{l}\text { Breakdown of operational costs by budget line } \\
\qquad \text { Ptas }(€)\end{array}$ \\
\hline \multirow{4}{*}{$\begin{array}{l}1962 \text { contingency } \\
\text { plan }\end{array}$} & $\begin{array}{c}\text { Partial plans (urban planning actions for la Riera de } \\
\text { les Arenes, el Torrent de Vallparadís and their buffer } \\
\text { zone) }\end{array}$ & $1,207,112(7,254.89)$ \\
\hline & $\begin{array}{l}\text { Repair and construction of water channels } \\
\text { (rainwater and urban waste water collectors) }\end{array}$ & $88,415,000(531,384.85)$ \\
\hline & $\begin{array}{l}\text { Paving and public works projects (reconstruction } \\
\text { and improvement) }\end{array}$ & $44,184,470(265,554.01)$ \\
\hline & Urbanization (reconstruction and improvement) & $18,875,000(113,441.03)$ \\
\hline \multirow{4}{*}{$\begin{array}{l}1963 \text { contingency } \\
\text { plan }\end{array}$} & Repair and reconstruction of municipal property & $8,810,798,27(52,953.96)$ \\
\hline & $\begin{array}{l}\text { Repair and construction of water channels } \\
\text { (rainwater and urban waste water collectors) }\end{array}$ & $21,604,659,81(129,846.62)$ \\
\hline & $\begin{array}{l}\text { Paving and public works projects (reconstruction } \\
\text { and improvement) }\end{array}$ & $57,328,465,25(344,551.01)$ \\
\hline & Urbanization (reconstruction and improvement) & $87,440,000,00(525,524.98)$ \\
\hline \multicolumn{2}{|c|}{$\begin{array}{l}1962 \text { contingency plan total budget } \\
1963 \text { contingency plan total budget } \\
\text { Total budget focused on urgent actions }\end{array}$} & $\begin{array}{c}152,681,582(917,634.79) \\
175,183,923.33(1,052,876.58) \\
\mathbf{3 2 7 , 8 6 5 , 5 0 5 . 3 3}(\mathbf{1}, \mathbf{9 7 0}, \mathbf{5 1 1 . 3 7})\end{array}$ \\
\hline
\end{tabular}

Source: Compiled from funding records from Terrassa's 1962 and 1963 contingency plans.

The following year, 1963, major works were initiated that completely transformed the north-western sector of the city. This was the diversion of la Riera del Palau. One of the main consequences, in terms of Terrassa's urban planning, was the clear demonstration of the watercourse as a boundary. Boix (1977) stresses that "the suburbs [...], following this intervention, were left on the other side, physically separated from the rest of the city". An outcome, intended or not, which shows just how quickly decisions are taken after a tragic episode such as this.

The PGOUs of 1965 (Baca Plan) and 1983. The will "to overcome the physical barriers"

In 1965, three years after the tragic flood, Terrassa's City Hall instructed the municipal architect, Joan Baca i Reixach, to draw up a new PGOU. In the face of the obvious chaos in the city's urban planning, and given the demographic challenges that the city faced (in ten years, the population of Terrassa had doubled thanks to intense migration from different regions of Spain), Baca drafted a substantially different plan to the earlier ones, within a budget limited to what the council could afford without getting itself into too much debt. ${ }^{7}$ The plan devoted a considerable part of the budget ( $13 \%$ or 54 million pesetas, equivalent to 321,000 euros) to the urbanization of Vallparadís Park, as Baldrich had planned in the 1951 PGOU. Most of the plan's budget was assigned to paving the city, the installation of a sewage system and to street lighting, in an exercise of urban improvement for the entire city, which, affected by demographic growth and unchecked urban sprawl, urgently needed urban services.

The Baca Plan was only the second PGOU to be passed in the entire history of Terrassa, passing the filter of both the City Hall and the interests of the local oligarchy. Even so, the

${ }^{7}$ The total budget was $418,590,042.31$ pesetas, equivalent to a little more than 2.5 million euros, divided into eight, five-year payments that the council undertook to pay off in 40 years, which is the same as an annual budget of $10,464,751.05$ pesetas. main criticism that can be levelled at the plan was the fact that approving a new plan, which replaced earlier provisions, is what ended up tipping the scales toward a too optimistic 40-year time horizon. And although it was finally approved, history shows that its previsions, scheduled in eight, five-year periods, were hardly ever met (Boix, 1983b).

Between 1965 and 1983, the council of Terrassa tried, unsuccessfully, to adopt a revised PGOU (1971) and a multimunicipal plan (1979). Some years later it actually succeeded in drafting and approving, thanks to the role played by the recently created Gerencia Municipal de Urbanismo (the municipal planning department), a new PGOU in 1983. The main proposal of the plan was the orderly growth and expansion of Terrassa by means of "overcoming its physical barriers". This expression, which is repeated throughout the document, refers specifically to the rieras, streets, roads, and railway lines on the city's periphery and which, according to the plan, needed to be intelligently managed, redeveloped and renewed. The plan proposed the building of fourteen new bridges (six across la Riera de les Arenes, seven over la Riera del Palau and one over el Torrent de Vallparadís) and the construction of an underground the railway line. Among other measures, it also proposed the drafting of a special plan for the future management of Vallparadís park, emphasizing the importance of transforming the rieras into new spaces of urban centrality: "It is not a question of building a road in the middle of el Torrent de Vallparadís, but rather of defining in the plan the best solution to ensure that the torrent is an element that stimulates relationships between the different parts of the city and that it can be accessed easily from outside; without this use putting into jeopardy its good environmental conditions" (Terrassa City Hall 1983a). Finally, the plan also foresaw the improvement of the sewage system in Terrassa. Among other projects, it proposed building a sewage treatment plant at the confluence of la Riera de les Arenes and another watercourse, la Riera de Rubí. 


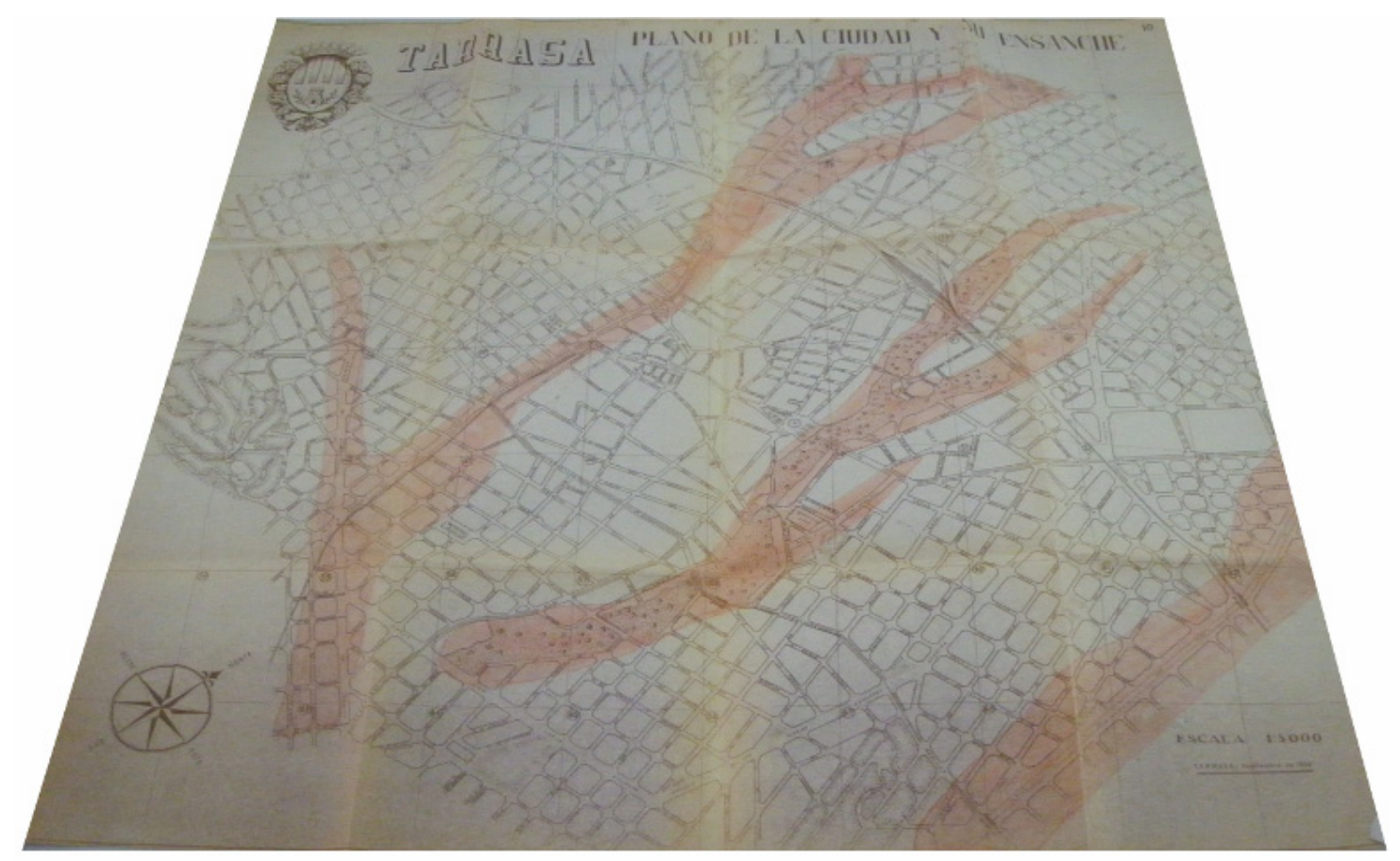

Figure 3. Perspective view of an old city map showing the areas of Terrassa most badly affected by the flood of 1962 . Clearly they coincide with the courses of the three main rieras in the city.

Source: Map contained in the annex to the 1962 and 1963 contingency plans.

We can state, with the benefit of hindsight, that the 1983 PGOU ended up being, in practice, one of the few successes in the history of Terrassa's urban planning; and we use the word "success" in the sense that the provisions of a plan, once approved, actually ended up being implemented. The 1983 PGOU was not only approved, but its proposals, albeit with some delays, were generally put into practice. The sewage treatment plant was inaugurated in $1994,{ }^{8}$ the underground railway line came into use in 1987, and two years later the special development plan for Vallparadís Park, which we discuss below, was approved.

The special urban development plan (PE) for Vallparadís Park (1989). The final step in the planning of the city centre's torrent

On 29 June 1980 the so-called special urban development plan (PE) for Vallparadís Park; drawn up by a multidisciplinary team of architects, biologists and lawyers, under the leadership of Manuel Ribas i Piera, architect and urban planner; was finally approved. The aim of the plan was to finalize the urbanization of Vallparadís Park, which extended over a length of 3.5 kilometres and covered an area of $400,000 \mathrm{~m}^{2}$. Clearly, this was the same goal as was set by the architect Manuel Baldrich in the first PGOU in 1951. The main work focused on providing adequate access routes from the city to the park, the construction of new car parking lots, the general landscaping of the space, the construction of sports facilities and the creation of a lake navigable on two levels fed by water from el Torrent de Vallparadís and from the urban network.

Although 13 million euros were initially budgeted for this work, the eventual investment rose to over 18 million (Alemany 2010). Thanks to a large sum of financial aid (1,185 million pesetas,

${ }^{8}$ Terrassa's water treatment plant, large enough to treat a flow of $75,000 \mathrm{~m}^{3} / \mathrm{day}$, not only served this city, but also the surrounding municipalities of Matadepera and Sant Quirze del Vallès. Initially it operated a physical-chemical process for cleaning the water, but in 1999 this was expanded with the creation of an activated sludge biological treatment (Moragas et al. 2012). equivalent to 7.1 million euros) from the European Cohesion Fund in 1996, work was able to go ahead on the project. This support, together with other financial contributions, ${ }^{9}$ meant that, between 1996 and 1999, much of the work on the central section of the park could be carried out. The determination of City Hall during the twenty years of work constructing the park and extending it south has been vital for raising money and for ensuring it did not run up too large a debt.

\section{The 2003 POUM. "Expand in order to integrate"}

In 1998, Terrassa City Hall initiated steps to review the PGOU approved in 1983, with the intention of updating its provisions taking into account the developments made in the Catalan urban planning law. ${ }^{10}$ The new POUM identified two of the most important challenges facing the city of Terrassa: an intraurban solution for the urban chaos in the city's planning directly attributable to the 1962 flood and the extra-urban expansion of the system of open spaces, based on the incorporation of a vast territory as a new metropolitan park.

The first strategy was concerned with the regulation, renovation and improvement of the hydraulic system used for the diversion of la Riera del Palau. The ten-year plan proposed completely covering over the river course in order to create "a large urban axis that would constitute a broad avenue linking up the city's neighbourhoods (...), while creating new fronts of urban

${ }^{9}$ In 1997, an injection of financing from the State Fund for Local Investment (FEII) provided 4.1 million pesetas (roughly 25,000 euros). In addition, Terrassa City Hall obtained other grants while it was engaged in building the park, including money from the State Fund for Employment and Local Sustainability (FEOSL), which allocated slightly more than 5 million euros to finance the fifth stage in 2010 .

${ }^{10}$ One year before the birth of the new urban plan, Ley 2/2002, de 14 de marzo, de urbanismo was passed. This act, exclusive to Catalonia, specified the provisions included in the law at the state level. One of the most visible changes was the adoption of a new name (Plan de Ordenación Urbanística Municipal, with the acronym POUM) replacing the former Planes Generales de Ordenación Urbana (PGOU). 
activity along its length" (Terrassa City Hall 2003a). Thus, the aim was to create a new central focus of attraction in the southern part of the city by building new lines of communication and developing new industrial activity and services. ${ }^{11}$ As a complement to this new urban focus, a proposal was made to expand Vallparadís Park southward to occupy an additional 10 hectares. The second major strategy concerned a proposed $20 \%$ increase in the functional area of the existing Natural Park of Sant Llorenç del Munt i Serra de l'Obac, so that the park's limits might coincide with Terrassa's urban perimeter. Finally, the development of a new metropolitan park was envisaged with an area of nearly 700 hectares in the northern part of the city, to be known as the Parc territorial dels torrents de la Grípia i de la Batzuca.

The 2003 POUM remains in force today, awaiting new economic resources so that its proposals and previsions can be put into effect. The new urban focus to the south of the city has yet to be fully developed, and proposals such as covering over la Riera del Palau and the extension of Vallparadís Park remain on hold. Thus, although the 10-year plan remains operative, the projects proposed have not been carried out, mainly because of the apparent lack of municipal revenues at a time of economic crisis throughout Europe.

\section{Conclusions}

The preceding case study for the city of Terrassa has been based primarily on an analysis of the local urban planning instruments generated by City Hall between the 1950s and the present day. Our study highlights the complexity of the processes that have led to the situation in which the city's three intermittent streams currently find themselves. This complexity has been conditioned, above all, by two factors: the city's physical environment (that is, the specific hydrographical characteristics of the site on which Terrassa sits) and the city's urban planning (that is, the ambivalent nature of local development plans from the point of view of their implementation).

Our study confirms that one of the key characteristics of the urban development of the three river courses has been the great obstacles encountered when seeking to implement the proposals contained in the local planning instruments in a coherent way, as well as obtaining definitive approval for the plans from City Hall. In seeking to comprehend these obstacles, we cannot ignore the fact that ownership of the urban land in Terrassa has been concentrated in the hands of just a few families (who have acted as a true lobby group at the local level, especially in the period between 1959 and 1975, during the Franco dictatorship). Seen in this light, it is readily apparent that the influence wielded by these

${ }^{11}$ Specifically, previsions were made for $283,985 \mathrm{~m}^{2}$ of land for new tertiary activities and $242,283 \mathrm{~m}^{2}$ for an industrial zone, which represent respectively $67.46 \%$ and $38.63 \%$ of the city's total development proposal. families greatly conditioned the adoption of certain decisions by City Hall (above all, land expropriation for urbanization). A clear example of this is that it was not until 1965 that the PGOU was finally approved, i.e. ten years after the change in Spain's planning regulations (ushered in with the 1956 land use legislation). Following the transition to democracy, Terrassa gained greater control over its future and its urban planning improved in one critical aspect: the city gained the power to implement its main proposals. The difference in urban planning from one stage to the other is quite evident. The measures taken in 1962, as a result of the catastrophic floods, highlight the overall lack of foresight and control over the urban growth of the city.

In a different vein, the urban planning of the three rieras in Terrassa during the period considered shows implicitly the undoubtedly fluvial dimension of the city. Although Terrassa does not compare to the classic model of a "river city", and while it has no rivers of any significant volume, the potential and the threats of the various rieras that cut across the urban space have always been more than evident. The local urban plans; which should dictate the basic lines of urban management throughout the municipality and which ought to deal with such issues as property ownership rights, the protection of the city's heritage and the increasing quality of life of its inhabitants; have always attached great value to the city-river interface as its principal stage. The "modest" river network that caused the great flood of 1962 is that which currently irrigates the city's largest central park, dictates the shape of the city's main roads and constitutes a physical barrier on the periphery that, in some cases, must still be overcome. Although limited and intermittent, water (either in the form of a riera, stream or secondary watercourse) has been ever present in the history and geography of the city of Terrassa. It is not surprising; therefore, that it has had a profound influence on the city's changing urban design.

\section{Acknowledgements}

Sincere thanks are due to lain Kenneth Robinson for his linguistic assistance. The accomplishment of the present study has been possible thanks to Formación de Profesorado Universitario (FPU) grant of Ministerio de Educación, Cultura y Deporte (Government of Spain). It has also been carried out in the frame of the research project CSO2012-39564-C07-06 of Ministerio de Economía y Competitividad (Government of Spain) and Grup de Recerca Ambiental Mediterrània 2014 SGR 825 (2014-2017) and 2009-SG-1515 (2009-2013).

\section{References}

Alemany, J 2010, 'Terrassa acabarà el pulmó verd del parc de Vallparadís després de 20 anys d'obres', El Punt-Avui 8 September. Available from: <http://www.elpuntavui.cat>. [17 March 2015]

APEM \& Environment Agency, 2010. 'Urban river regeneration in Manchester. Transforming the Dark River Irwell', Mersey Basin Campaign, p.1-26.

Boix, J 1977, Tarrasa 1877-1977. Cien años de urbanismo, Caja de Ahorros de Terrassa, Terrassa.

Boix, J 1983a, 'Historia de los planes de ordenación de Terrassa (IV): El Plan Baldrich (1951)', Diario de Tarrassa, Suplemento $n^{\circ} 6$, 1 February. p. 1-3.
Boix, J 1983b, 'Historia de los planes de ordenación de Terrassa (V): El llamado Plan Baca (1965)', Diario de Tarrassa, Suplemento $n^{\circ} 7,8$ February. p. 1-3.

Bravard, J P 2004, 'Le façonnement du paisaje fluvial de Lyon: choix urbanistiques et héritages de I'histoire hydromorphologique', Boletín de la Asociación de Geógrafos Españoles, 37, p. 17-32.

Djament-Tran, G 2012, 'The heritage waterfront landscape of globalization. The case of Paris metropole city on the Seine', Portplus, Association for the Collaboration between Ports and Cities, p. 1-9. 
Donofrio, J T 2007, 'Preservation as a tool for waterfront revitalization: design, management and financing solutions from Vancouver, Boston and London', Master Thesis, University of Pennsylvania, 164 p., Pennsylvania.

Hans, H 2008, 'Changes on the waterfront - transforming harbour areas: comparison and evaluation of waterfront development in two contexts: San Francisco Bay Area and Hamburg', Germany, IURD Working Paper Series, Institute of Urban and Regional Development, Berkeley, p. 37-48.

Moretti, M 2008, 'Cities on water and waterfront regeneration: a strategic challenge for the future', Grundtvig, II Meeting Rivers of Change - River Cities, Warsaw (Poland), July $24^{\text {th }}-27^{\text {th }}$.

Moretti, M 2010, 'Valorisation of waterfronts and waterways for sustainable development', International Scientific Conference about Poltva River, Ukraine, November $19^{\text {th }} 20^{\text {th }}$

Moragas-Bouyat, L, García-Fernández, E.B, Robusté Cartró, J, Aguiló-Martos, P, Gassó-Barqué, J, Fernández-Junquera, S, César-Galobardes, E, García-Del Campo, I 2012, 'Experiencias de explotación en Cataluña en estaciones depuradoras con procesos de tratamiento biológico híbridos: los casos de la EDAR Gavà-Viladecans y la EDAR Terrassa', Ingeniería Civil, no. 168, pp. 121-130.

Moral Ituarte, L 1997, 'El agua en la organización del espacio urbano: el caso de Sevilla y el Guadalquivir' in Ciutat i riu: l'aigua en l'organització de l'espai urbà, eds A Ribas \& Saurí D, Documents d'Anàlisi Geogràfica, Bellaterra, pp. 117-127. Panareda, J M 2009, 'Evolución en la percepción del paisaje de ribera', Boletín de la Asociación de Geógrafos Españoles, no. 51, pp. 305- 324.

Penning-Rowsell, E C 1997, 'Rius i ciutats: amenaces i potencialitats' in Ciutat i riu: l'aigua en l'organització de l'espai urbà, eds A Ribas \& Saurí D, Documents d'Anàlisi Geogràfica, Bellaterra, pp. 23-34.

Ribas-Piera, M 1992, 'El torrent de Vallparadís, parc central de Terrassa: decisiu per passar plana a la seva història urbana', Espais. Revista del Departament de Política Territorial $i$ Obres Públiques, no 36, pp. 22-26.

Ribas, A 2012, 'Tornar a viure de cara al riu', Revista de Girona, no 270 , pp. $60-65$.

Tastsoglou, A \& Vagiona, D 2012, 'Urban waterfront regeneration: the Thessaloniki - Greece case study', Protection and Restoration of the Environment XI, Sustainable Landscape Architecture, Management and Restoration, p. 2224-2233.

Ureña, J M 1999. 'Ordenación de las áreas fluviales en las ciudades: un enfoque metodológico', Revista de Obras Públicas, no 46, pp. 4-15.

\section{Documentary sources}

Terrassa City Hall 1951, Plan General de Ordenación Urbana.

Terrassa City Hall 1951a, Plan General de Ordenación Urbana, Segunda parte, Ordenación urbana y rural, Ordenación de la ciudad de Terrassa, p. 217

Terrassa City Hall 1951b, Plan General de Ordenación Urbana, Primera parte, Información urbanística, La vivienda, p. 100

Terrassa City Hall 1958, Plan General de Ordenación Urbana

Terrassa City Hall 1958a, Plan General de Ordenación Urbana, Memoria, Consideraciones generales, p. 10

Terrassa City Hall 1958b, Plan General de Ordenación Urbana, Memoria, Consideraciones generales, p. 12

Terrassa City Hall 1962, Plan de urgencia

Terrassa City Hall 1963, Plan de urgencia

Terrassa City Hall 1965, Plan General de Ordenación Urbana

Terrassa City Hall 1983, Plan General de Ordenación Urbana
Terrassa City Hall 1983a, Plan General de Ordenación Urbana, Objetivos de la revisión del Plan General de Terrassa, Consideraciones técnicas sobre los temas expuestos a las compariciones, p. 113

Terrassa City Hall 1987, Plan especial de ordenación del Parque de Vallparadís

Terrassa City Hall 2003, Plan de Ordenación Urbanística Municipal

Terrassa City Hall 2003a, Plan de Ordenación Urbanística Municipal, Memoria, Las líneas estratégicas del nuevo Plan, Proyecto de infraestructuras de ciudad, p. 27

\section{Mentioned legislation}

Ley de 12 de mayo de 1956 sobre Régimen del Suelo y Ordenación Urbana

Ley 19/1975, de 2 de mayo, de reforma de la Ley sobre Régimen del Suelo y Ordenación Urbana

Real Decreto 2159/1978, de 23 de junio, por el que se aprueba el Reglamento de Planeamiento para el desarrollo y aplicación de la Ley sobre Régimen del Suelo y Ordenación Urbana

Ley $2 / 2002$, de 14 de marzo, de urbanismo 